\title{
Ethnologies
}

\section{South By Southwest: A Road Map to Alternative Country. By \\ Brian Hinton. (London: Sanctuary Publishing, 2003. Pp 304, ISBN 1-86074-461-3, plok)}

\section{Gillian Turnbull}

Volume 26, numéro 2, 2004

Québec - Ethnologie du proche

Québec - Ethnology At Home

URI : https://id.erudit.org/iderudit/013761ar

DOI : https://doi.org/10.7202/013761ar

Aller au sommaire du numéro

\section{Éditeur(s)}

Association Canadienne d'Ethnologie et de Folklore

ISSN

1481-5974 (imprimé)

1708-0401 (numérique)

Découvrir la revue

Citer ce compte rendu

Turnbull, G. (2004). Compte rendu de [South By Southwest: A Road Map to

Alternative Country. By Brian Hinton. (London: Sanctuary Publishing, 2003. Pp 304, ISBN 1-86074-461-3, pbk)]. Ethnologies, 26(2), 331-333.

https://doi.org/10.7202/013761ar d'utilisation que vous pouvez consulter en ligne.

https://apropos.erudit.org/fr/usagers/politique-dutilisation/ 
South By Southwest: A Road Map to Alternative Country. By Brian Hinton. (London: Sanctuary Publishing, 2003. Pp 304, ISBN 1-86074461-3, pbk)

Brian Hinton's attempt at uncovering the history of alternative country is a prime example of how this type of book can grow out of control and become limitless. Is it possible to write a comprehensive account of a genre that has "officially" been in existence for fifteen years, but finds its roots in music reaching back over the century? Could any authority on the subject discuss every single artist, recording, experiment, mutation, combination, and twist that inevitably occurs in any genre? It is unlikely, however in South by Southwest, Hinton endeavours to do just that.

It is with sympathy for the enormity of the task that I read Hinton's book. In addition to the daunting undertaking, Hinton also had to contend with the very problem of definition when writing about the alt-country. Having never had the benefit of a precise explanation of its parameters, the term alt-country has been used to define any type of roots, Americana, non-mainstream country, or old-time music that has emerged in the last few decades. In short, alt-country is more about the attitude than its musical characteristics. Its industry is centred in Austin rather than Nashville; it is anti-corporate, anti-glitter, and anti-gloss; it is unconventional and DIY; it is, as Hinton says in quoting Justin Tubb, "the music of the working man, the farmer, the trucker, the factory worker." This is the first full-scale effort to concretize alt-country; other histories have ignored vital elements of its background, and have mythologized certain events as being the beginning of alt-country while excluding other necessary information. The ensuing confusion over what exactly constitutes alt-country is hardly surprising, and has possibly put authors off extracting a full history of it.

Hinton reaches far back to the early twentieth century to begin his book. It is not explicitly chronologically structured, but ends up following a sequential timeline by moving from the roots of alt-country to the emergence of a recognized genre and its branches and further experiments. Hinton discusses how alt-country's roots lie in the oldtime music of the South, in folksong collections and the early country recordings of the Carter Family and Jimmie Rodgers. He leaves no stone unturned as he unearths the numerous contributors to the current 
genre: Woody Guthrie's straightforward folk tunes; the rockabilly/ country recordings of Johnny Cash and Elvis Presley; the introspective lyrics and acoustic instrumentation of 1960s folk music; the countryrock revolution on the Byrds' Sweetheart of the Rodeo; the outlaw attitude of Waylon Jennings and Willie Nelson; the hip, easygoing country splashes in the Eagles; the rebelliousness, energy, and simplicity of punk; the experimental attempts of new wave, and the list goes on. By delving into alt-country's ancestry in such a way, Hinton demonstrates that the aesthetics of alt-country do not lie in rock or country alone, but country may be added to rock for musical colouring in the form of a pedal steel or banjo, while country may plump itself up with the driving rhythm of electric rock guitar or the raw vocal intensity of punk.

With this as the basis for further exploration, Hinton sets himself up to examine more specifically the recent developments in alt-country. He investigates the important artists thriving in alt-country's branches such as low-fi, gothic country, and the avant-garde, and he acknowledges the importance of place as he does a loop of the United States, displaying the variants that materialize from geographical particularities. To conclude, Hinton looks at current artists who have drawn on the long lineage he has mapped out, and reveals that tradition is still heralded even in alt-country, as it becomes the foundation upon which the genre builds new directions.

As is to be expected, there are several artists and places missing from Hinton's book. While it is pointless to list them here, it is maybe more constructive to note that he also does not give equal space to artists, and often privileges those who appear to be his favourites. A prime example of this is the undeserved ten pages that Uncle Tupelo and its offshoots (Son Volt, Wilco) get while Willie Nelson only receives half a page of attention from him. He tries to justify it by changing the definition of alt-country to what he believes is the common perception by stating that, "Alt-country has developed its own style and constraints... its godfathers are Gram Parsons and Neil Young, rather than Hank Williams or Dock Boggs. There are lots of electric guitars and drums, and not too many banjos. The really inventive thing tends to be the lyrics, world-weary and quirky." What he has done here is perpetuate the myth that alt-country began in 1990 with the seminal recording, No Depression, by Uncle Tupelo. Hinton thereby discredits 
his 150 preceding pages of history leading up to that moment by both suggesting that Uncle Tupelo is where it all began, and by giving them more credit than any other artist in the book.

In addition, there is not a strong sense of narrative to carry the book. Transitions are awkward, often moving from artist to artist without a perceivable link between them. It is frequently ambiguous as to how the book connects; more often than not, it seems as though it is a compilation of blurbs about artists rather than a moving chronology of events. However, this is perhaps an inescapable consequence of writing such a history, as it would be impossible to connect all and smooth over that which is disjointed.

Despite its faults, South By Southwest is undoubtedly a vital source for those seeking more information on the history of alt-country. Hinton has gone beyond expectations in digging out lesser-known artists, recordings, press materials, and interviews to give a far-reaching account of the genre, while including the renowned icons of alt-country as well. While his writing is slightly awkward at times, it is nonetheless accessible to those unfamiliar with musicological writings; his detailed musical descriptions of songs and albums are not esoteric, but are clear and well-presented. In addition, although there is no discography, Hinton does include a bibliography and a list of broadcasts, websites, magazines, festivals, compilation CDs, and DVDs that further enable the reader to explore alt-country on their own. Alt-country has been in need of a thorough work such as this, and Hinton's book has successfully brought the genre further into the public eye. 